\title{
EnVironmental Quality and Preservation- Mapping Benthic Ecosystems and Environments in the Florida Keys
}

\section{Introduction}

The fragile coral reefs of the Florida Keys form the largest living coral reef ecosystem in the continental United States. Lining the shallow outer shelf approximately 5 to $7 \mathrm{~km}$ seaward of the Keys (Fig. 1), the reefs have national aesthetic and resource value.

\section{The Problem}

As recently as the 1970 s, Florida's coral reefs supported a diverse ecosystem (Fig. $3)$. Since then, the vitality of all ecosystem components has declined markedly due to a variety of environmental stressors (e.g., Porter and Porter, 2002). Corals are succumbing to bleaching and diseases (Figs. 4, 5). Species that are the building blocks of solid reef framework are increasingly being replaced by species that do not construct reef framework. Algal proliferation is increasing competition for space and for the hard surfaces needed by coral larvae for settlement. Decline of the coral reef ecosystem has significant negative implications for Florida's economic vitality, ranging from viability of the tourism industry attracted by the aesthetics, to sport and commercial fishing drawn by the resources. At risk of loss are biologic habitats and reef resources, including interconnected habitats for endangered species.

What are the reasons for this decline? Is the decline natural change, or are effects of human activities contributing factors? Adverse activities range from leisure diving, ship groundings, and fishery exploitation to impacts from farmland runoff, nutrient influx, airborne contaminants, and groundwater pollutants. To what extent are they affecting coral reefs, and can they be mitigated?

One of the first steps to differentiate between natural change and the effects of human activities is to view the big picture. Mapping various aspects of the reef tract achieves this goal - and answers the question, how did coral reefs respond to past environmental change, before the influence of man? A clear understanding of the geologic and biologic history of a region, any region, is fundamental to:

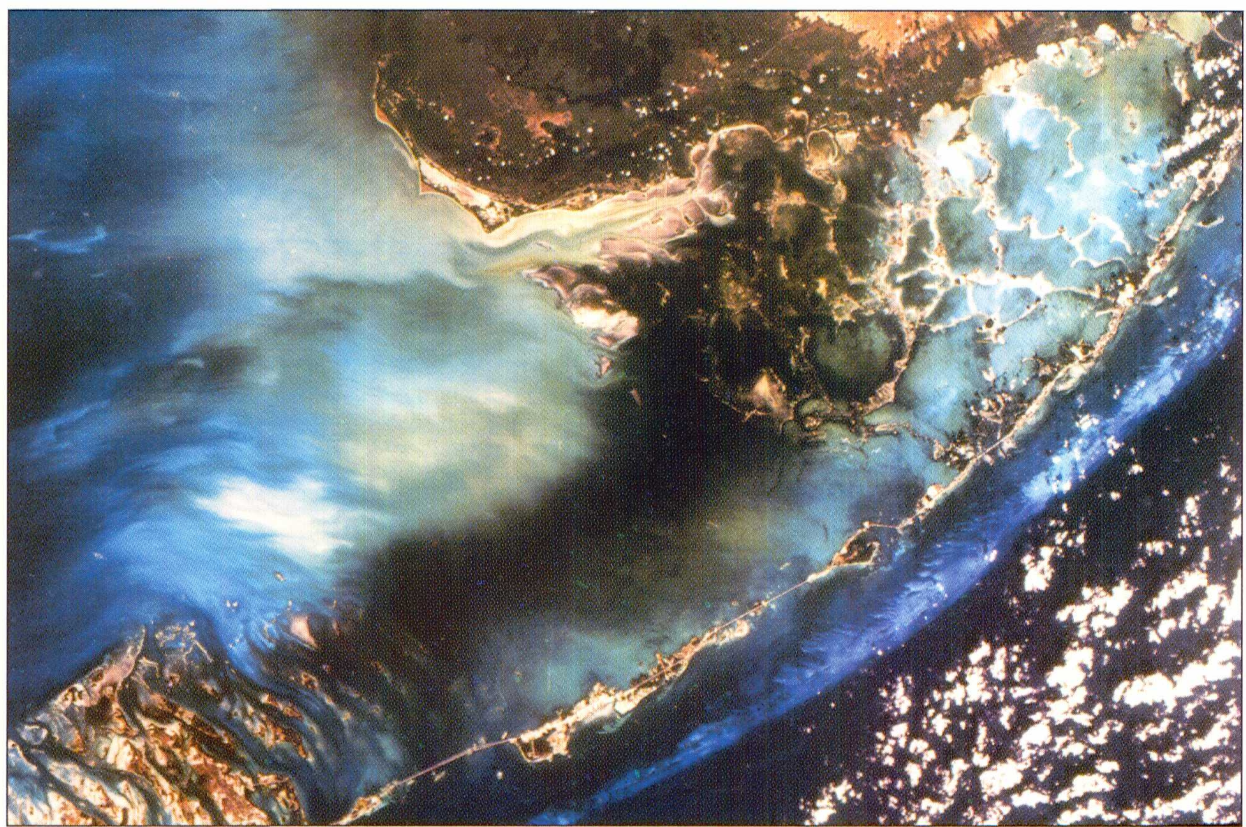

Fig. 1. Enhanced Thematic Mapper Plus image, acquired from the Landsat 7 satellite in May 2000, shows the four geographic components of the South Florida Ecosystem: the Everglades (southernmost part), Florida Bay, the Florida Keys, and the reef tract. The curved chain of islands (upper and middle Keys) is an emergent 125-ka coral reef (Fig. 2). The lower Keys (left foreground) are emergent tidal bars of the same age. Seaward of the Keys lie submerged habitats of the inner shelf, Hawk Channel, sands and Holocene reefs on the shallow outer shelf (pale blues), and 30-m-high 80-ka reefs at the shelf edge. Gulf of Mexico is at left, Straits of Florida at right.

- recognizing the cause and effect of what transpired there in the past;

- establishing current status in order to monitor changes; and

- assessing how management and conservation of existing natural resources within that region can effectively be implemented.

\section{The Project}

In 1997, the U.S. Geological Survey's (USGS) Coastal and Marine Geology Program undertook a comprehensive 7-year-long mission to consolidate, synthesize, and map new and existing geologic and biologic information into a digitized regional database and one-volume reference source for reefs within a contiguous part of the Florida Keys National Marine Sanctuary. The area mapped is between central Key Largo and Halfmoon Shoal in the Gulf of Mexico. The purpose was to examine the natural evolution and demise of several reef ecosystems over the past $325 \mathrm{ka}$ (Fig. 2), with an eye toward gaining a better understanding of the reef decline observed today.

\section{Project Highlights}

Digital maps of the reef tract were developed using a combination of techniques, including shelf-wide geophysical data, aerial photomosaics of seabed features and habitats, and thin-section analyses of surface sediments. The maps comprise the most detailed geologic database in existence for the sanctuary, covering $\sim 2,130$ $\mathrm{km}^{2}$. The regional maps show (a) depth to Pleistocene bedrock (Fig. 2; Lidz, 2000a); (b) thickness of Holocene reefs and sediments (Lidz, 2000b; Lidz et al., 2003); (c) distribution of primary skeletal sedimentary grains in surface sediments in 1989 (Lidz and Hallock, 2000); and (d) benthic ecosystems and environments (this report).

This Open-File Report introduces the benthic ecosystems and environments map. The map 


\section{Holocene Epoch $=10 \mathrm{ka}$ to present Pleistocene Epoch $=1.8 \mathrm{Ma}$ to $10 \mathrm{ka}$ \\ $k a=$ thousand years old \\ $\mathrm{Ma}=$ million years old}

Figure 2. Scientific terms for the most recent periods of geologic time.

was derived from field knowledge combined with on-screen interpretation and digitizing of scanned aerial photomosaics. The map can be viewed in depth in close-up map tiles in the one-volume reference source (Lidz et al., 2005).

\section{Geologic Framework}

Bedrock along the southeast Florida shelf consists of Pleistocene limestone composed of fossil coral reefs and oolite (e.g., Hoffmeister and Multer, 1968; Enos and Perkins, 1977). Ooids are concentric grains of calcium carbonate that precipitate from sea water under certain conditions. When cemented, they form limestone called oolite. The bedrock underlies reefs of the present Holocene ecosystem.

The Florida Keys are divided on the basis of composition and orientation into the upper, middle, and lower Keys. The upper and middle Keys are composed of a coral reef that grew parallel to the shelf margin (Fig. 1). The lower Keys consist of oolitic tidal bars that formed perpendicular to the margin at the southwest end of the reef.
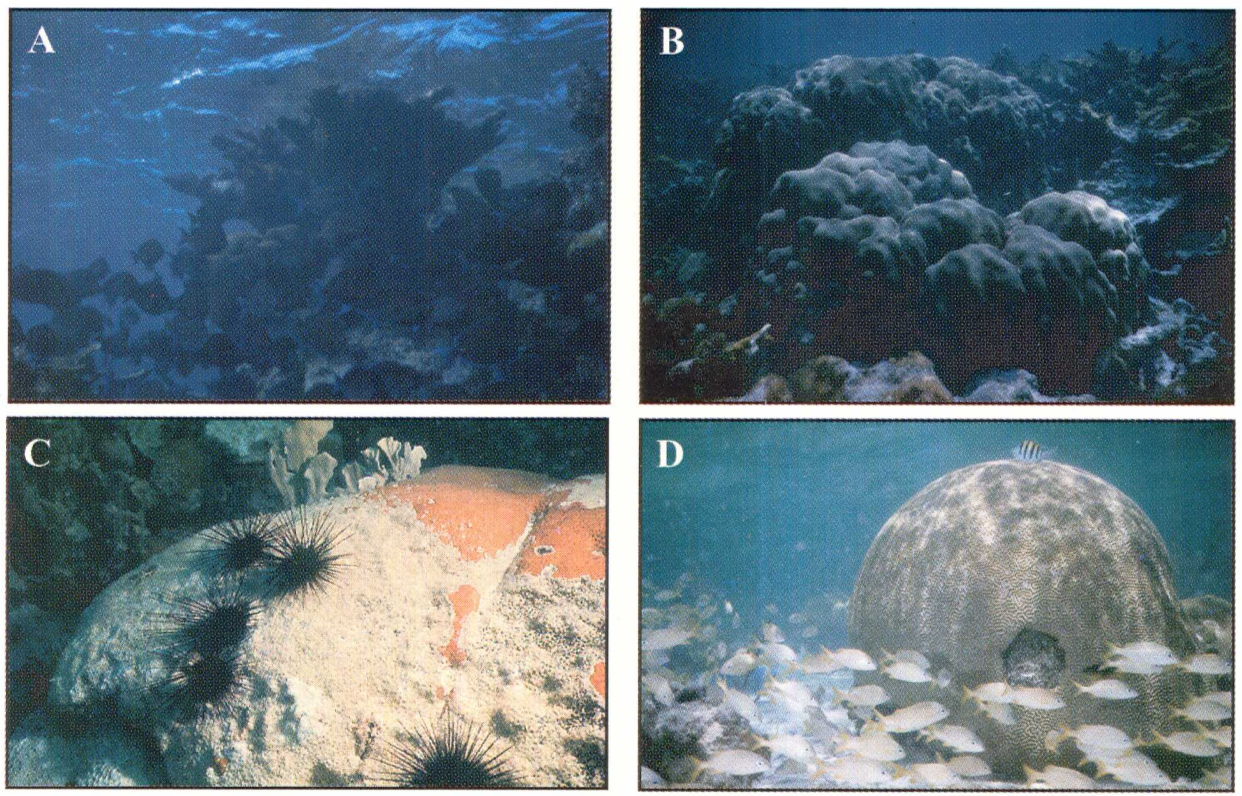

Figure 3. Photos of a healthy reef system. (A) Stand of healthy Acropora palmata with numerous fish. (B) Reef-framework builders Montastrea annularis (massive head coral, foreground) and Acropora palmata (platy moosehorn or elkhorn coral, background). (C) Urchin Diadema antillarum grazes dead area (foreground) on a species of Siderastrea before 1983. Though the coral is essentially dead, browsing urchins in a healthy reef keep dead surfaces free of algae. Live coral polyps are at upper right. Blades of live Millepora complanata are in the background. (D) Healthy Colpophyllia natans and fish. where, is reflected in the high concentrations of skeletal coral grains present in the surface sediments (e.g., Aronson and Precht, 1997; Lidz and Hallock, 2000).

\section{Benthic Ecosystems}

Benthic ecosystems on the Florida shelf vary in size, shape, and distribution due to location, water depth, onshore and offshore geomorphology and bottom type, and different exposures to southeasterly prevailing winds and waves along the curved shelf edge. Onshore ecosystems are largely defined by geology (elevation; presence, thickness, and type of soil; and fresh- or saltwater settings) and urban development (vegetated or non-vegetated). Offshore ecosystems are largely defined by inner- and outer-shelf settings and by presence of a bedrock depression beneath Hawk Channel. Roughly 19 primary types of habitat designated by various authors dominate the marine realm (Plate 1). Each has its distinct ecologic characteristics and biologic community (described below). A pie chart accompanying the benthic ecosystems map shows that three habitats are predominant, encompassing $63.5 \%$ of the mapped area. Notably, live coral reefs, mainly patch reefs, comprise less than $1 \%$ of the mapped area. Roughly $3,141 \mathrm{~km}^{2}$ or $\sim 33 \%$ of the $9,600 \mathrm{~km}^{2}$ within the Marine Sanctuary have been mapped.

The following subheadings match the colorcoded map units and pie chart (Plate 1). The map units are listed roughly in a seaward direction. The first two units and the last in the map key are terrestrial units. All others are marine units. Area (in $\mathrm{km}^{2}$ and $\%$ ) given in subheading descriptions indicates the spatial area of that map unit within the total area mapped.

Roads/airports cover $8.43 \mathrm{~km}^{2}$, or $0.3 \%$ of the area of the Florida Keys that was mapped.

Subaerially exposed Pleistocene limestone and/or spoil fill $\left(\mathbf{7 5 . 9 0} \mathrm{km}^{2}, \mathbf{2 . 4 \%}\right)$ : Pleistocene limestone exposed on the Keys is either bedrock in depositional position or spoil islands created from cut-and-dredged bedrock. Urban development and manmade canals have modified these areas. A thin band of limestone with little vegetation is present between the freshwater environment of the hardwood forest and saltwater habitat of the mangroves.

Hardwood forest $\left(37.62 \mathrm{~km}^{2}, \mathbf{1 . 2 \%}\right)$ : Hardwood forests consist of tropical hardwoods that grow in a thin soil on elevated areas of exposed bedrock. Spoil islands do not support hardwoods. Endangered tree snails live on the tree limbs, and various small 
rodents occupy the forest. Several species of snakes, including the diamondback rattlesnake, inhabit this ecosystem. Terrestrial wildlife is limited mainly to vegetated areas.

\section{Mangrove forest and peat $\left(69.40 \mathrm{~km}^{2}\right.$,} $2.2 \%$ ): The mangrove zone fringes the shoreline and displays a characteristic zonation of the three major varieties. The most dominant, the red mangrove with its characteristic prop roots is found on the seaward edge of the forest. The black mangrove with its vertical pneumatophores occupies the middle area. The white mangrove lines the landward parts of the stand. Large areas of mangrove forests overlie thick ( $>1 \mathrm{~m}$ ) accumulations of mangrove peat. Many attached organisms such as filamentous algae, hydroid colonies, barnacles, and tunicates are found on the stems and roots of the mangroves. Several gastropods, tree oysters, and crabs are found on the more prominent aerial parts of the plants. A large assortment of animals lives in the shallow water at the base of mangroves, including flatworms, annelids, jellyfish, fiddler crabs, horseshoe crabs, shrimp, and small forage fish. Hundreds of natural tidal channels and manmade canals cut the mangroves and mangrove-peat accumulations. Mangroves are protected trees throughout Florida.

Tidal creek $\left(61.65 \mathrm{~km}^{2}, \mathbf{2 . 0 \%}\right)$ : Tidal creeks nurture wetland nurseries and threatened and endangered species. Marine grasses populate much of the creek-channel floors. The sediments mostly consist of calcareous algae and occasional pieces of limestone that have eroded from channel walls, or corals and molluscs that have washed in during storms. If storms are sufficiently severe, currents can scour the creek channels to bedrock.

\section{Carbonate sand on Pleistocene coral reef} limestone $\left(46.15 \mathrm{~km}^{2}, \mathbf{1 . 5 \%}\right)$ : Sand-covered bedrock is usually found adjacent to the mangrove fringe along a nearshore rock ledge that borders the seaward side of the Keys. The inner part of the ledge is covered with thin $(<30 \mathrm{~cm})$ sands. The outer part is usually bare rock. Both inner and outer ledge zones host an inshore hardbottom habitat, which is also found along intertidal parts of the Keys and in tidal channels. The rock ledge is shallow ( 0 to $4 \mathrm{~m}$ ) and harbors different biota depending on sediment thickness and current velocity. Generally, green and brown algae, sparse sea grasses, Sargassum weed, gorgonians, and several species of sponges, most notably large loggerhead sponges, populate the inshore hardbottom habitat along with non-reef-forming stony corals and coralline red algae. Sea grasses are dense in 30- to 50-cm-deep, circular, sediment-filled holes that pockmark the limestone surface. Because sunlight generally
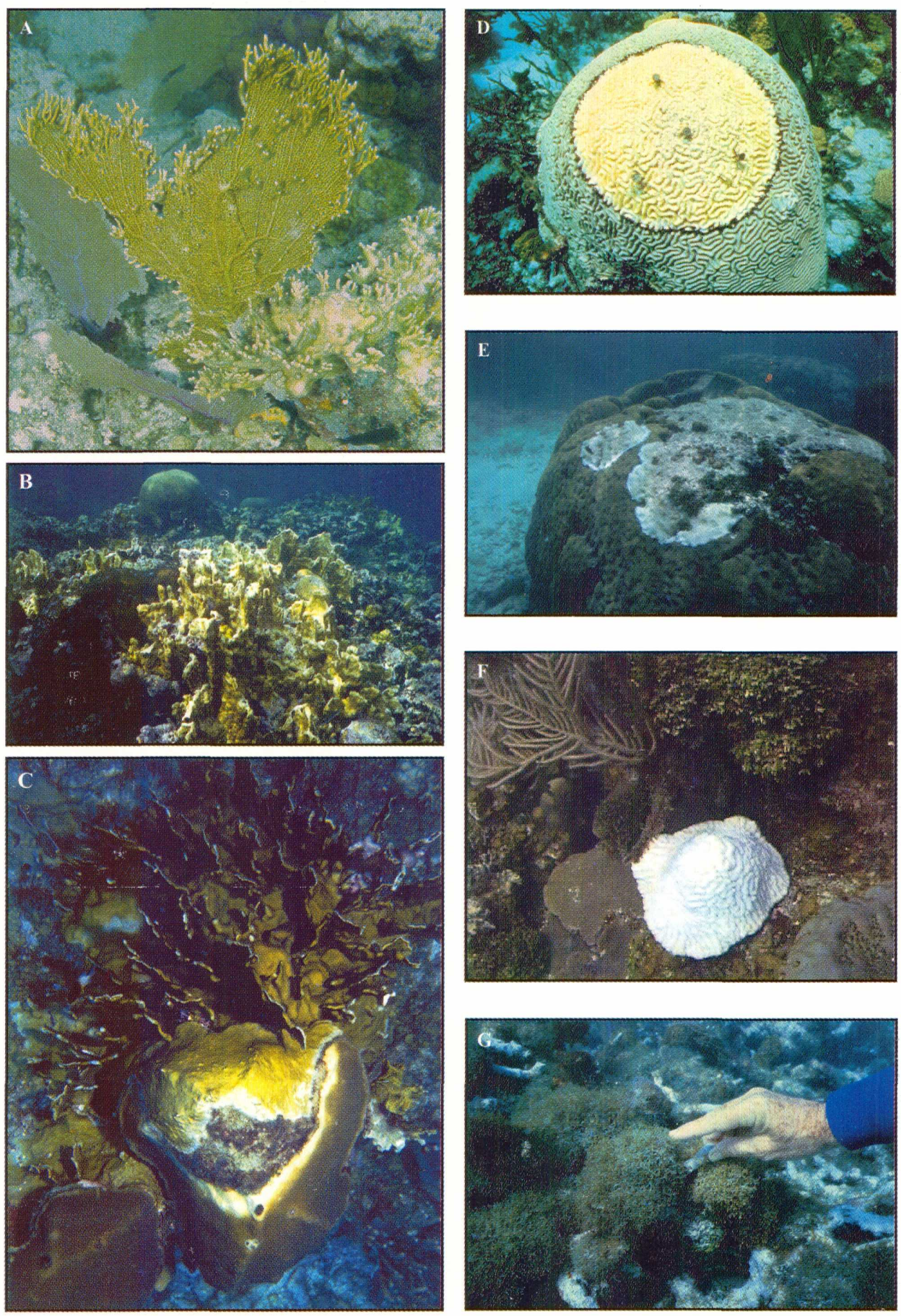

Figure 4. Photos show examples of reef decline. (A) Living layer of the hydrocoral Millepora alcicornis (encrusting growth habit) coats an entire sea fan. Uncoated fans are at left and bottom left. (B) Field of $M$. complanata (bladed habit) surrounds a brain coral (Diploria or Colpophyllia species) in background. (C) Millepora complanata overgrows a dying Montastrea annularis head coral. (D) Black-band disease on a colony of $M$. annularis. Nails were imbedded to measure rate of disease spread. This and other types of band disease can destroy a 200-year-old coral in a single summer. (E) White-band disease on M. annularis. (F) Bleached Meandrina species. A coral is said to bleach when it expels the symbiotic algae needed for photosynthesis, color, and building its skeleton. Bleaching is a sign of stress, not a disease. If conditions that caused bleaching return to normal fairly rapidly, the coral will regain the algae. If conditions do not allow bleaching to reverse, coral mortality may result. (G) Typical overgrowth of turf algae on coral rubble in 1992. Fleshy algal mats retard establishment of coral larvae. Lack of the herbivorous black spiny sea urchin Diadema antillarum in all photos indicates the photos were taken after a Caribbean-wide die-off of the urchin in 1983-84. Cause of the die-off, from which the urchin has not recovered, is unknown.

penetrates to the ledge surface, marine life is abundant and diverse, though less luxuriant than that in the offshore hardbottom habitat (senile coral reef zone). 

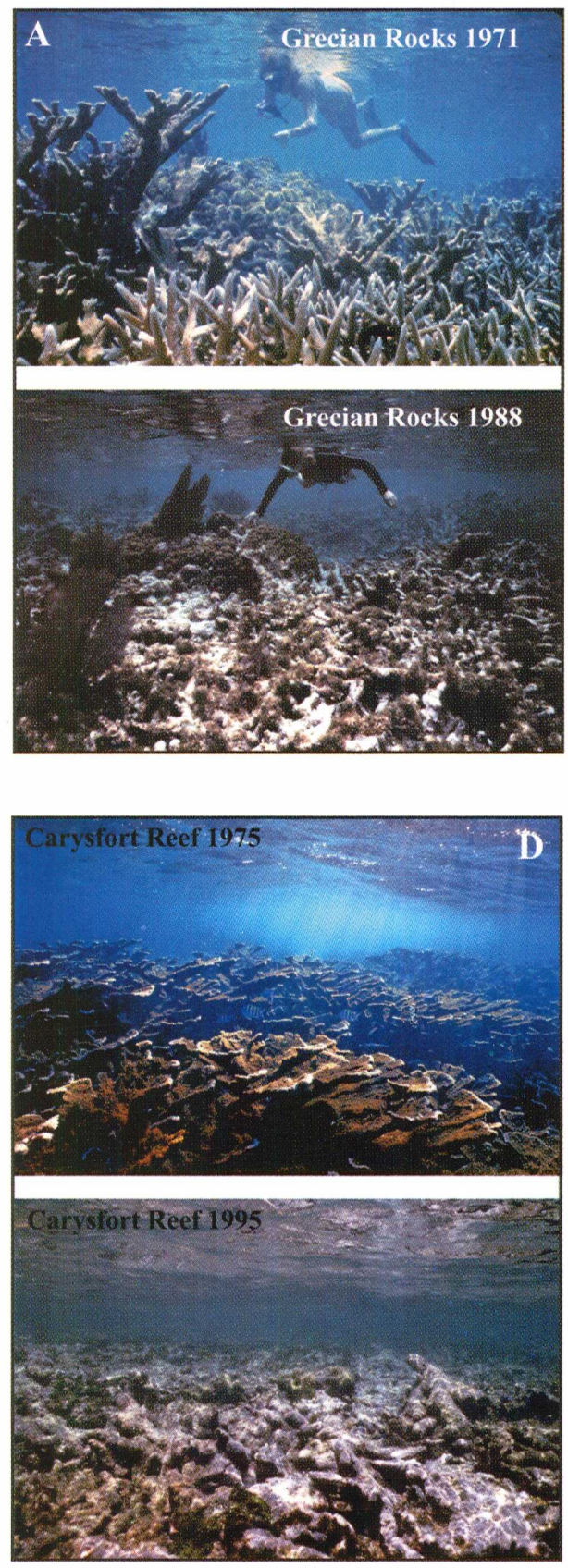

The inshore community reflects highly variable conditions. Rainfall, atmospheric temperature, and submarine groundwater seepage affect seawater temperature and salinity. Minor changes in tidal amplitude, wind intensity, and wind direction may result in noticeable changes in turbidity. Nearshore, there is little water movement, and turbidity is generally low except during storms. The inshore community is more diverse off the upper and lower Keys than off the middle Keys, reflecting the influence of Florida Bay water on middle Keys organisms. Winter storms bring cold, sediment-laden bay waters to the ecosystem, and hurricanes produce warm, turbid waters. Only the hardiest organisms are able to survive in the inshore hardbottom habitat, which has both restricted-circulation and high-velocity
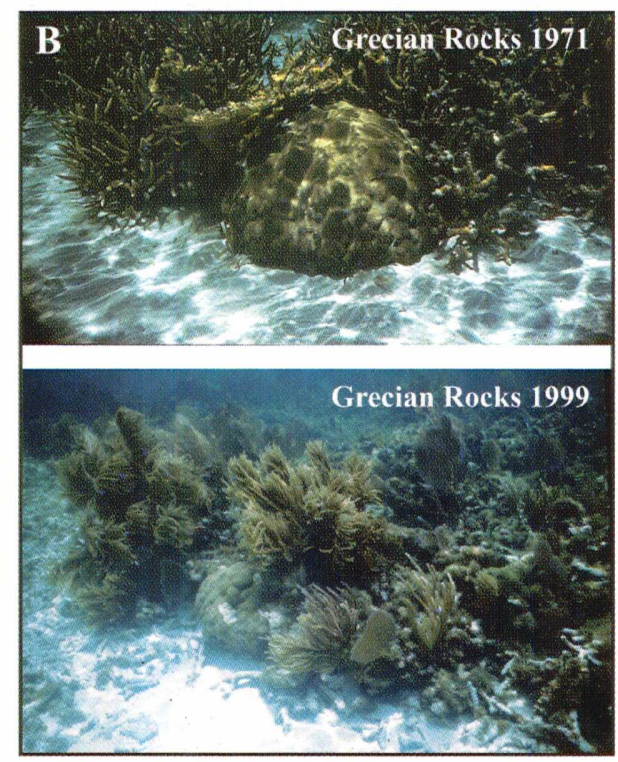

(A) From Shinn et al. (2003)

(D) Photos courtesy of Phillip Dustan, College of Charleston, SC
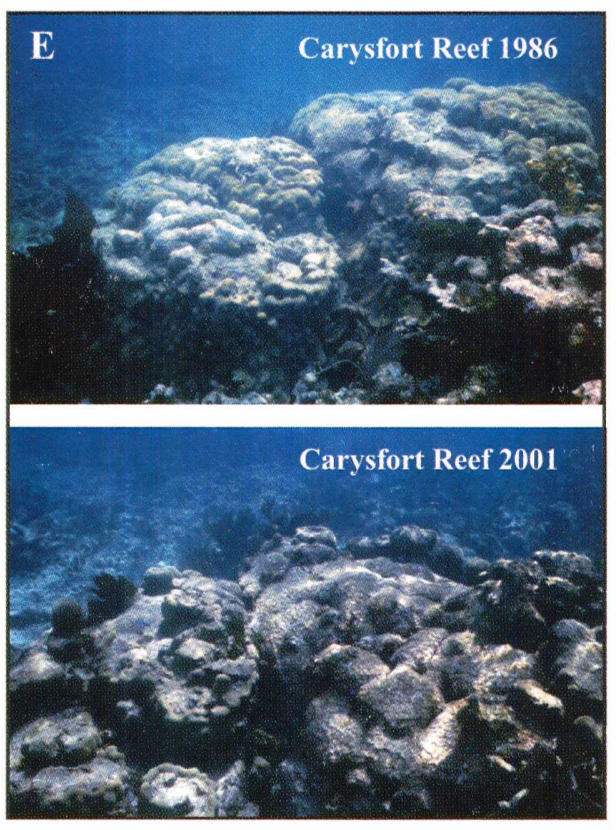

communities. Unlike deeper-water corals, nonreef-building corals have developed a mucus system that can withstand the high suspendedsediment levels sometimes found in the shallow water.

Various species of sponges dominate highvelocity communities located in tidal channels and in seaward regions between islands and patch reefs. Strong currents generally sweep across channel communities.

Bare Pleistocene coral reef limestone $\mathbf{8 9 . 4 2}$ $\mathbf{k m}^{2}, \mathbf{2 . 8 \%}$ ): Inshore hardbottom habitat is also found on the outer edge of the nearshore rock ledge. Head corals populate this area of the ledge in the lower Keys.

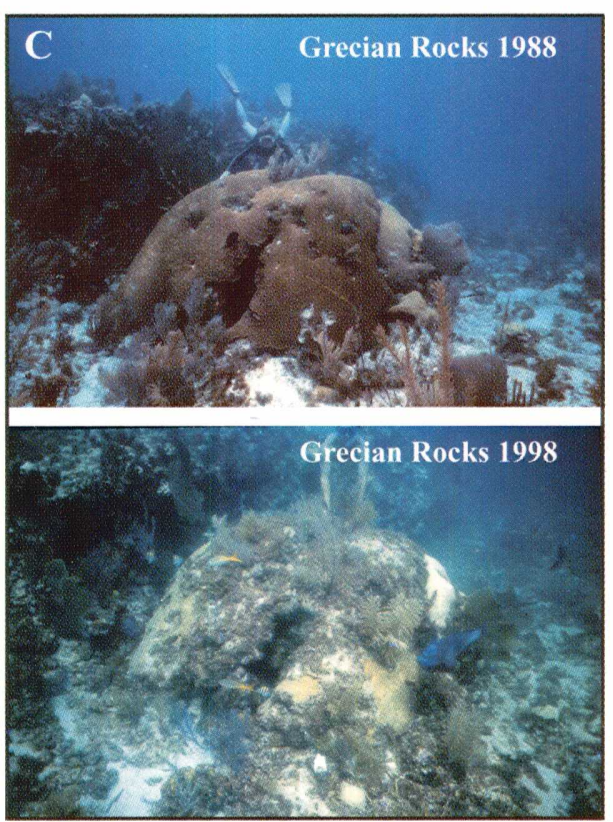

Figure 5. Photo pairs show vitality of head and branching corals in the recent past (top photos) and their present state (bottom photos) at Grecian Rocks $(A-C)$ and Carysfort Reef (D-E) in the Florida Keys. Each pair is of the same corals through time. Note coral rubble and presence of macro-algae, sea whips, sea fans, and absence of fish in the bottom photos. The photo sets show that overall structure, function, and dynamics of the present reef ecosystem, its ecologies, and biota are in a distinct state of decline.

Grass-covered sand on rock ledge (4.98 $\mathbf{k m}^{2}, \mathbf{0 . 2 \%}$ ): Though the seaward part of the ledge is essentially bare rock, the landward part is sandy in places or covered by sand and grass in others.

Coralline red algae $\left(0.48 \mathrm{~km}^{2}, \sim 0.0 \%\right)$ : Abutting inshore hardbottom habitat in localized areas is the very small coralline red-algae or shoal-fringe habitat, in which a zonation of distinctive organisms colonizes the windward edge of shoal banks near the Keys. The best known such banks are at Tavernier and Rodriguez Keys off Key Largo (Turmel and Swanson, 1976). Where best developed, this zone consists of shallow $(<\sim 1 \mathrm{~m})$ areas of coralline red algae and a deeper (to $\sim 2 \mathrm{~m}$ ) area of finger coral. Turtle grass and green algae are subordinate. Thickets of the shoal-fringe community act as protective borders by dissipating energy that might otherwise erode muddy sediments of the shoal banks. Parts of the coralline red-algae zone are subaerially exposed during spring low tides.

Marine grasses on lime mud $\left(864.70 \mathrm{~km}^{2}\right.$, 27.5\%): The most extensive seabed habitat consists of marine grasses on lime mud and occupies nearly all of Hawk Channel and its westward extension south of the MarquesasQuicksands ridge (Plate 1). The dominant 
grass is turtle grass. Grasses are sparse or absent in deeper parts where depth and turbidity attenuate sunlight. Bioturbated lime mud contains skeletal grains of calcareous algae and fragmented molluscs. (Sediments are said to be bioturbated or disturbed when burrowing organisms have mixed them.) This ecosystem begins at the base of an abrupt 30 -cm-high scarp at the seaward edge of the nearshore rock ledge, where sediments pinch out at the landward edge of the Hawk Channel bedrock depression. Sediments thicken seaward to an average of $\sim 4 \mathrm{~m}$ within the channel. Large loggerhead sponges are scattered throughout the zone. Burrowing ghost shrimp and sea cucumbers create abundant sediment mounds. Sea-biscuit urchins live on the surface, unable to plow through the mud because of grass rhizomes.

\section{Bare lime mud or grass-covered muddy} carbonate sand $\left(302.87 \mathrm{~km}^{2}, 9.6 \%\right)$ : This zone, found in Hawk Channel, is often associated with patch reefs. Most bare lime mud occurs off the upper Keys where current flow and winnowing are dampened by a lack of tidal passes. The sediment is mixed lime mud and carbonate sand similar to that in the grasscovered lime-mud areas but is less bioturbated. Faunas are greatly reduced. Few organisms live in grass-free areas, which are severely scoured during storms. Grasses either were removed or never grew in this zone. Grasses re-colonize such spots very slowly due to lack of light attributed to turbidity and deeper water depths.

\section{Marine grasses on carbonate sand $\mathbf{5 8 7 . 9 0}$}

$\mathbf{k m}^{2}, \mathbf{1 8 . 7 \% )}$ : The second largest seabed habitat is the sand/grass community along the outer shelf. Mixed grasses, usually turtle grass and the cylindrical manatee grass, inhabit this zone. The sand is composed mainly of fragmented calcareous algae. The sea-biscuit urchin lives throughout this zone. The cushion starfish is found in the landward part. The Queen conch, Queen helmet conch, and King conch are found mainly in the seaward part, especially near the coral-rubble and coralrubble/carbonate-sand zones. Storms can create grass-free blowouts, exposing underlying sand. Sea grasses on sand provide shelter, nurseries, and food. Grasses also stabilize sandy and muddy bottoms and enhance water quality by reducing turbidity through entrapment and removal of suspended grains from the water column.

Bare carbonate sand $\left(\mathbf{5 4 2 . 8 3} \mathrm{km}^{2}, \mathbf{1 7 . 3 \%}\right)$ : Composing the third largest habitat, bare carbonate sands are typically $\sim 1$ to $5 \mathrm{~m}$ thick. White Bank off the upper Keys, an area of thick (4 to $6 \mathrm{~m}$ ) sands extending $\sim 48 \mathrm{~km}$ along the outer shelf off north Key Largo, is an example. Unnamed areas of bare sand occur all along the outer shelf. The sand primarily consists of calcareous algal plates with grains of corals, molluscs, bryozoa, echinoid spines, and shells of microorganisms. In shallow areas, sand grains are rounded and polished but are not oolitically coated (concentrically coated with carbonate). In places, the sand is partially cemented to form friable rocks, especially around holes of burrowing organisms. Clean calcareous sands contain a specialized fauna composed of polychaete worms and small burrowing organisms (holothurians, sea urchins, shrimp, jawfish, razorfish, bivalve mollusks, crabs, and other invertebrates). Sand dollars and red-heart sea urchins plow just beneath the surface. During periods of calm seas, diatom mats and blue-green algal mats partially stabilize the upper surface. Storms remove grasses that may start growing, resulting in blowouts that help maintain this zone.

Coral rubble and carbonate sand $\left(4.48 \mathrm{~km}^{2}\right.$,

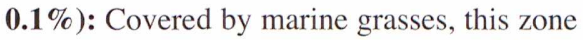
is usually transitional with the coral-rubble zone located behind skeletal Holocene reefs on the fossil shelf-edge reef. Sargassum weed and grasses generally grow attached to scattered rubble. Organisms include Queen conchs on beds of fossil branching corals coated with calcareous algae and green and brown algae.

Coral rubble $\left(7.49 \mathrm{~km}^{2}, 0.2 \%\right)$ : Concentrated by storms, coral rubble often forms elongate fields behind major shelf-edge Holocene reefs. Queen conchs favor rubble sites. Alcyonarians and gorgonians are not common due to frequent reworking of rubble substrate during storms.

Senile coral reef $\left(\mathbf{7 0 . 1 9} \mathrm{km}^{2}, \mathbf{2 . 2 \%}\right)$ : Senile coral reefs, or reefs that are no longer actively accreting solid reef framework, comprise the offshore hardbottom habitat. Senile reefs consist largely of linear shelf-edge hardbottoms populated by alcyonarians and hydrocorals (stinging corals) with scattered heads of star and branching corals. Holocene branching corals have constructed well-developed spurs (now skeletal) and grooves on these reefs (Shinn, 1963). Discontinuous outer-shelf coral-rock ridges are primarily found in this senile-reef zone (Lidz, 2004). Algae with holdfasts populate areas of thin $(2-10 \mathrm{~cm})$ sediment. Grasses with rhizomes (turtle grass, thin-bladed shoal grass, and cylindrical manatee grass) populate areas of thicker cover (up to $30 \mathrm{~cm}$ ). Abundant alcyonarians and gorgonians occupy stabilized, dead coral surfaces. Gorgonians are often oriented perpendicular to local current flow to feed efficiently and thus provide information about typical current patterns in the area (Booker, 1997). Large barrel and loggerhead sponges are also common.
Live coral reef $\left(22.73 \mathrm{~km}^{2}, 0.7 \%\right)$ : Live corals today are generally limited to an uneven distribution of patch reefs shoreward of the outer-shelf reefs. Some patch reefs are found in Hawk Channel. Most are found $\sim 3$ to $7 \mathrm{~km}$ from the Keys, between Hawk Channel and the outer-shelf reefs. Thousands occur off the upper and lower Keys. Although rare in the middle Keys, patch reefs are found close to the Keys in areas where they are protected from the influence of Florida Bay waters. Patch reefs usually consist of large head corals with abundant alcyonarians, gorgonians, and calcareous algae. Clusters of various species can cover areas as large as $100 \mathrm{~m}$ to several kilometers in diameter. Patch reefs are often spherical but can also demonstrate lateral expansion, growing parallel to the shelf margin.

Sand halo around patch reef $\left(39.08 \mathrm{~km}^{2}\right.$, $1.2 \%)$ : Sand haloes generally surround patch reefs. A combination of wave action around resistant (coral) structures and foraging by organisms closely associated with the corals excavates grasses to create the conspicuous haloes.

Manmade treasure-salvor sand holes $\mathbf{( 0 . 0 1}$ $\mathbf{k m}^{2}, \sim 0.0 \%$ ): Treasure salvors search for buried shipwreck artifacts using mechanical devices called mailboxes. Mailboxes consist of a 0.6- to 1.2-m-diameter metal elbow that deflects a boat's prop wash downward to displace large amounts of sand. The holes created are usually about $10 \mathrm{~m}$ in diameter and $6 \mathrm{~m}$ deep. Digitizing enlargements of the scanned aerial photos revealed one such area where 11 teardrop-shaped and circular holes were visible in a transect across a grass-covered-sand area on the outer shelf. It is not known when those footprints were made. The largest hole is estimated from on-screen measurement to be about 60 by $120 \mathrm{~m}$ in size. The salvors' transect covers a distance of approximately 1.5 $\mathrm{km}$. Areal extent of the salvor holes mapped is very small. Not visible at the map scale, the salvor holes are not shown in the legend or pie chart on the plate.

Bare Pleistocene oolitic limestone (250.33 $\mathbf{k m}^{2}, \mathbf{8 . 0 \%}$ ): The oolite that forms the lower Florida Keys extends westward as submerged bedrock on the Marquesas-Quicksands ridge (Plate 1; Shinn et al., 1990). Sponges, gorgonians, and Sargassum weed populate areas where the oolite is free of sediment. Karst-like depressions 30 to $50 \mathrm{~cm}$ deep pockmark the surface, generally nearshore in the lower Keys. These depressions contain sand and dense sea grasses. A mixed-grass and bare-oolite zone is transitional between areas of bare oolite and carbonate sand on oolite. Calcareous algae and turtle grass are the primary organisms on the sands. 
Carbonate sand on Pleistocene oolitic limestone $\left(\mathbf{1 7 . 5 6} \mathrm{km}^{2}, \mathbf{0 . 6 \%}\right)$ : Sands on the Marquesas-Quicksands oolite are generally coarse-grained and consist almost exclusively of fragmented plates of green calcareous algae (Hudson, 1985). The sands are generated on the ridge, as indicated by deeper bedrock around the ridge (Lidz, 2000a). Strong reversing tidal currents mold the sands into 5-m-high north-trending tidal bars on which 1-m-high west-trending sand waves are transposed. Always in motion, the sands are being transported westward off the ridge. Although skeletal Holocene corals overlie isolated topographic highs of linear bedrock corals at the edges of the ridge, few corals are alive there today. Wintertime Gulf of Mexico water temperatures retard coral growth.

Outlier reef $\left(36.29 \mathrm{~km}^{2}, 1.2 \%\right)$ : Outlier reefs are located on the upper-slope terrace and are separated from the margin by empty or partially filled backreef troughs (Lidz et al., 1991). The outlier reefs have high relief (up to $30 \mathrm{~m}$ ), are discontinuous, and extend for more than $200 \mathrm{~km}$ along the margin. They are best developed off the lower Keys where four tracts have been identified (Lidz et al., 2003). These reefs are late Pleistocene (e.g., Toscano and Lundberg, 1999), with a thin ( 3.4 m) cap of skeletal Holocene corals. Loggerhead and vase sponges are the dominant organisms in this zone. Scattered head corals of all kinds are present along with scattered staghorn corals and gorgonians. These organisms are typical of offshore hardbottom communities.

Where outlier reefs are absent, the upperslope terrace is generally covered with $\sim 3$ to $4 \mathrm{~m}$ of bare carbonate sand, the same sediment thickness as is found on most of the shelf. Algal nodules consisting of alternating layers of coralline algae and encrusting foraminifera (shelled protozoa) characterize the sands. Where outlier reefs are present, the sands likely also contain coral rubble swept landward from the reefs into their backreef troughs. Light attenuation due to water depth and common turbidity preclude growth of sea grasses in this zone.

\section{Summary}

The benthic ecosystems and environments map is the fourth in a comprehensive mapbased dataset for a contiguous area of the southeast Florida shelf. The map series includes the area that extends from The Elbow (a shelf-edge reef off central Key Largo) to the west end of The Quicksands (Gulf of Mexico). The datasets are intended to provide geologic and biologic information integral to sound resource-wise management and decision-making policies.
Although many organisms responsible for some of the coral diseases have recently been isolated and identified, their sources are still not known. Have the organisms always been present in the water column and simply multiplied to lethal levels, or have they been imported to the reef environment through human-induced airborne and water-borne activities? Studies to resolve these and other issues concerning stressors that affect coral reefs are ongoing. The evidence of human activities contributing to global reef decline is growing, however, and can no longer be ignored. Still, even with mitigation of their impacts, it also is not known whether stressed coral reefs can recover. Full knowledge of the naturally occurring and interacting processes specific to a reef-rimmed region is necessary to pursue answers to these questions. Mapping geologic and biologic components provides this historic perspective.

\section{Selected References}

Aronson, R.B., and Precht, W.F., 1997, Stasis, biological disturbance, and community structure of a Holocene coral reef: Paleobiology, v. 23, no. 3, p. 326-346.

Booker, J., 1997, Mangrove communities, in Gallagher, D., Causey, B.D., Gato, J., and Viele, J. eds., The Florida Keys Environmental Story, A Panorama of the Environment, Culture and History of Monroe County, Florida: Seacamp Association, Inc., Big Pine Key, Fla., p. 49-52.

Enos, P., and Perkins, R.D., 1977, Quaternary Sedimentation in South Florida: Geological Society of America Memoir 147, 198 pp.

Hallock, P., and Schlager, W., 1986, Nutrient excess and the demise of coral reefs and carbonate platforms: PALAIOS, v. 1, p. 389-398.

Hoffmeister, J.E., and Multer, H.G., 1968, Geology and origin of the Florida Keys: Geological Society of America Bulletin, v. 79, p. 1487-1502.

Hudson, J.H., 1985, Growth rate and carbonate production in Halimeda opuntia, Marquesas Keys, Florida, in Toomey, D.F., and Nitecki, M.H., eds., Paleoalgology: Contemporary Research and Applications: Berlin, Heidelberg, Springer-Verlag, p. 257-263.

Lidz, B.H., 2000a, Bedrock Beneath Reefs: the Importance of Geology in Understanding Biological Decline in a Modern Ecosystem: U.S. Geological Survey Open-File Report 00-046, 4 p., 1 Plate.

Lidz, B.H., 2000b, Reefs, Corals, and Carbonate Sands: Guides to Reef-Ecosystem Health and Environment: U.S. Geological Survey Open-File Report 00-164, 6 p., 1 Plate.

Lidz, B.H., 2004, Coral reef complexes at an atypical windward platform margin: Late Quaternary, southeast Florida: Geological Society of America Bulletin, v. 116, no. 7, p. 974-988.
Lidz, B.H., and Hallock, P., 2000, Sedimentary petrology of a declining reef ecosystem, Florida reef tract (U.S.A.): Journal of Coastal Research, v. 16 , no. 3 , p. 675-697.

Lidz, B.H., Hine, A.C., Shinn, E.A., and Kindinger, J.L., 1991, Multiple outer-reef tracts along the South Florida bank margin: Outlier reefs, a new windward-margin model: Geology, v. 19, p. 115-118.

Lidz, B.H., Reich, C.D., and Shinn, E.A., 2003, Regional Quaternary submarine geomorphology in the Florida Keys: Geological Society of America Bulletin, v. 115, no. 7, p. 845-866, plus oversize color plate of Pleistocene topographic and Holocene isopach maps.

Lidz, B.H., Reich, C.D., and Shinn, E.A., 2005, Systematic mapping of bedrock and habitats in the Florida Keys National Marine Sanctuary: U.S. Geological Survey Data Series DS-xxx (DVD).

Mallinson, D., Hine, A., Hallock, P., Locker, S., Shinn, E., Naar, D., Donahue, B., and Weaver, D., 2003, Development of small carbonate banks on the South Florida platform margin: Response to sea level and climate change: Marine Geology, v. 199 , p. 45-63.

Multer, H.G., Gischler, E., Lundberg, J., Simmons, K.R., and Shinn, E.A., 2002, Key Largo Limestone revisited: Pleistocene shelf-edge facies, Florida Keys, USA: Facies, v. 46, p. 229-272.

Porter, J.W., and Porter, K.G., eds., 2002, The Everglades, Florida Bay and Coral Reefs of the Florida Keys: An Ecosystem Sourcebook: CRC Press, Boca Raton, FL, 1024 pp.

Shinn, E.A., 1963, Spur and groove formation on the Florida reef tract: Journal of Sedimentary Petrology, v. 33, p. 291-303.

Shinn, E.A., Lidz, B.H., and Holmes, C.W., 1990, High-energy carbonate sand accumulation, the Quicksands, southwest Florida Keys: Journal of Sedimentary Petrology, v. 60, no. 6, p. 952-967.

Shinn, E.A., Reich, C.D., Hickey, D.T., and Lidz, B.H., 2003, Staghorn tempestites in the Florida Keys: Coral Reefs, v. 22, p. 91-97.

Toscano, M.A., and Lundberg, J., 1999, Submerged late Pleistocene reefs on the tectonically stable S.E. Florida margin: High-precision geochronology, stratigraphy, resolution of substage 5a sealevel elevation, and orbital forcing: Quaternary Science Reviews, v. 18, p. 753-767.

Turmel, R.J., and Swanson, R.G., 1976, The development of Rodriguez Bank, a Holocene mudbank in the Florida reef tract: Journal of Sedimentary Petrology, v. 46, no. 3, p. 497-518.

\section{For more information, please contact: \\ Barbara H. Lidz 600 4th Street South \\ St. Petersburg, FL 33701 \\ phone: $727-803-8747 \times 3031$ \\ fax: $727-803-2030$ \\ blidz@usgs.gov}

